shown by paper chromatography (in a propylene glycol-toluene system) as a very slowly moving spot.

A. BodÁnszky

J. KOLLONITSCH

Research Institute of the

Pharmaceutical Industry, Budapest. Oct. 11.

'Nature, 164, 443 (1949).

\section{Detection of lodine-containing Compounds on Paper Chromatograms}

Bowden, Maclagan and Wilkinson have described ${ }^{1}$ the use of the ceric sulphate - arsenious acid reaction for the detection of micro-quantities of iodinecontaining compounds on paper chromatograms. A difficulty encountered in this laboratory was the fading of the background colour due to the presence of traces of iodine in the atmosphere. This can be prevented by spraying the chromatograms, immediately on completion of the catalytic reaction, with a 1 per cent solution of $o$-phenylenediamine in acetone and drying in air. The stable chocolate-coloured background formed by reaction of excess ceric sulphate with the amine gives a greatly increased contrast with the white spots, and the life of the chromatogram is limited only by the decomposition of the cellulose by the acid present in the original reagent.

$$
\text { K. FLETCHER }
$$

P. G. Stanlex

Department of Clinical Research,

University College Hospital Medical School, London, W.C.l. March 1.

1 Bowden, C. H., Maclagan, N. F., and Wilkinson, J. H., Biochem. J., 59, 93 (1955).

\section{The System Niobium-Silicon and the Effect of Carbon on the Structures of Certain Silicides}

THE phase dirgram of the niobium-silicon system has been established by melting-point determinations, $\mathrm{X}$-ray examination and metallography, and is shown in Fig. 1. Alloys were prepared in the form of beads weighing 1-2 gm. by melting the constituents together in an argon arc-furnace ${ }^{1}$ : the metals used were 'Matthey' standards and the silicon was Johnson, Matthey and Co.'s 'Hyperpure'. Meltingpoint measurements were made in the furnace by a technique described earlier ${ }^{2}$.

Three intermediate phases, $\mathrm{Nb}_{4} \mathrm{Si}, \mathrm{Nb}_{6} \mathrm{Si}_{3}$ and $\mathrm{NbSi}_{2}$, are present in the system. That of com. position $\mathrm{Nb}_{4} \mathrm{Si}$ is formed peritectically at about $1,950^{\circ} \mathrm{C}$. from $\mathrm{Nb}_{5} \mathrm{Si}_{3}$ and the melt. From metallographic and X-ray examinations, it is evident that this compound is isomorphous with $\mathrm{Ta}_{4} \mathrm{Si}$ and $\mathrm{Zr}_{4} \mathrm{Si}$, but the $D O_{19}$ structure of the $\mathrm{Ta}_{4} \mathrm{Si}$ phase reported by Kieffer, Benesowsky, Nowotny and Schachner ${ }^{3}$ has not been detected in alloys arc-melted from components of high purity. The phase $\mathrm{Nb}_{8} \mathrm{Si}_{3}$ melts congruently at $2,480^{\circ} \mathrm{C}$, and exists in two modifications, ' $\alpha-\mathrm{Nb}_{8} \mathrm{Si}_{3}$ ' stable at low temperatures, and ' $\beta-\mathrm{Nb}_{8} \mathrm{Si}_{8}$ ' the high-temperature phase. The $\alpha-\beta$ transformation lies between $1,900^{\circ}$ and $2,100^{\circ} \mathrm{C}$. Phases with structures corresponding to $\alpha$ - and $\beta-\mathrm{Nb}_{5} \mathrm{Si}_{3}$ have been found in systems of silicon with the neighbouring transition metals of Groups IV, V and VI. Powder photographs of arc-melted specimens of $\mathrm{V}_{8} \mathrm{Si}_{3}, \mathrm{Cr}_{5} \mathrm{Si}_{3}, \mathrm{Mo}_{5} \mathrm{Si}_{3}$ and $\mathrm{W}_{5} \mathrm{Si}_{3}$ suggest that these compounds are isomorphous with the $\beta$-form of $\mathrm{Nb}_{5} \mathrm{Si}_{3}$, and that arc-melted $\mathrm{Ta}_{5} \mathrm{Si}_{3}$ is isomorphous

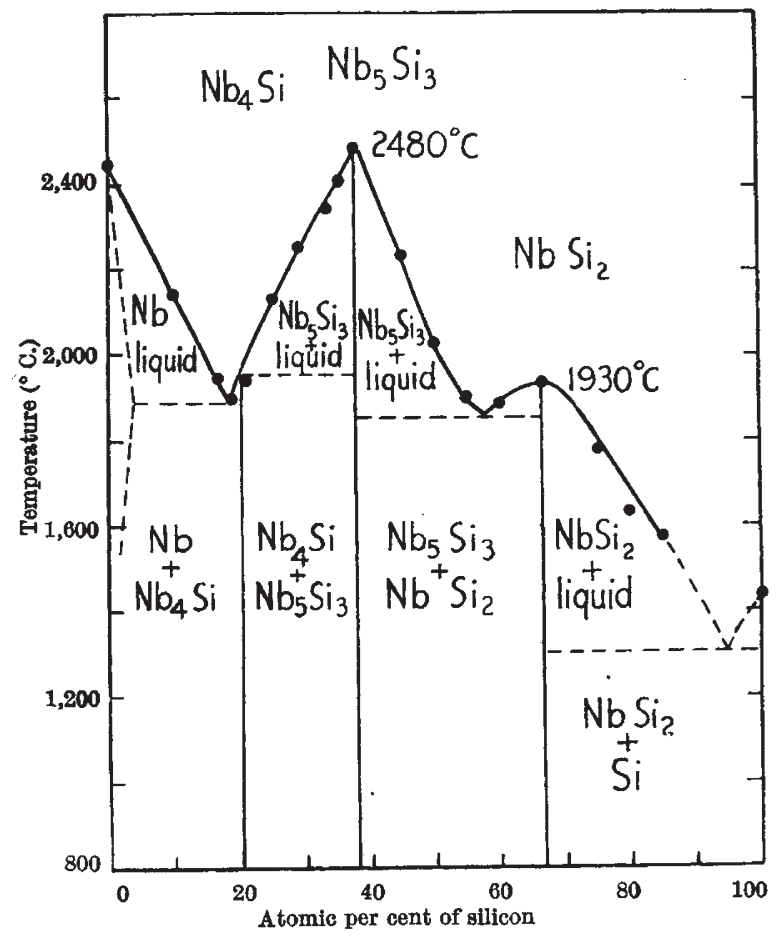

Fig. 1. Niobium - silicon system. •, Observed melting points

with the $\alpha$-form. In an investigation of alloys prepared by hot-pressing in graphite moulds, Schschner, Cerwenka and Nowotny ${ }^{4}$ determined the structures of several silicides of the composition $\mathrm{M}_{5} \mathrm{Si}_{3}$. They reported that $\mathrm{V}_{8} \mathrm{Si}_{3}, \mathrm{Mo}_{8} \mathrm{Si}_{3}$ and $\mathrm{Nb}_{5} \mathrm{Si}_{3}$ had the $D 8_{8}$ structure, but this structure was not found in the arc-melted silicides used in the present work. Carbon is a very probable contaminant in hot-pressed samples, and to determine whether carbon contamination accounts for the discrepancy in results, the $\mathrm{M}_{5} \mathrm{Si}_{3}$ silicides were re-melted in the arc furnace with 1-2 wt. per cent of coconut charcoal. In all cases the addition of carbon caused the formation of $D 8_{8}$ structures.

The melting point of $\mathrm{NbSi}_{2}$ has been determined as $1,930^{\circ} \mathrm{C}$., and a eutectic is formed between this compound and $\mathrm{Nb}_{5} \mathrm{Si}_{3}$ at $1,850^{\circ} \mathrm{C}$. and 58 atomic per cent silicon. At the niobium end of the diagram, silicon lowers the liquidus to about $1,880^{\circ} \mathrm{C}$., the eutectic temperature between $\mathrm{Nb}_{4} \mathrm{Si}$ and niobium. The terminal solubilities of silicon in niobium and niobium in silicon have not been investigated. An appreciable solubility of silicon in niobium is probable, a lattice expansion of $3 \cdot 299_{3}-3 \cdot 308_{3} \mathrm{kX}$. being observed in powder compacts sintered at $1,300^{\circ} \mathrm{C}$.

I thank Dr. G. A. Geach for suggesting this investigation, and for his continued interest in it, and also Dr. T. E. Allibone, director of the Associated Electrical Industries Research Laboratory, for permission to publish this communication.

\section{A. G. KNAPTON}

Research Laboratory,

Associated Electrical Industries, Ltd. Aldermaston Court,

Aldermaston, Berkshire. Dec. 8.

' Geach, G. A., and Sunmers-Smith, J. D., Metallurgia, 42, 153 (1950). 2 Geach, G. A., and Summers-Smith, J. D,, J. Inst. Met., 80, 143 (1951). ${ }^{3}$ Kieffer, R., Benesowsky, F., Nowotny, H., and Schachner, H., Z. Metall., 44, 242 (1953).

‘ Sehachner, H., Cerwenka, E., and Nowotny, H., Mh. Chem.. 85, 245 (1954). 